\title{
REGIONAL DISPARITIES RELATED TO SOCIO-ECONOMIC DETERMINANTS OF AGRICULTURE IN THE ROMANIAN PLAIN
}

\author{
Irena MOCANU, Ines GRIGORESCU, Bianca MITRICĂ \\ Elena-Ana POPOVICI, Monica DUMITRASCU \\ Institute of Geography, Romanian Academy
}

\begin{abstract}
The structure and pattern of agriculture in Romania has been facing significant changes over the past decades in relation to the contextual social, political and economic transformations. The current study is seeking to assess the determinants of agriculture in the main agricultural region of Romania (Romanian Plain) based on selected socioeconomic factors. The authors selected nine socio-economic indicators (agricultural surface, labour renewal index, economic dependency index, economically active population, employment in agriculture, vitality index, share of young labour, share of female population and roads and railway density) which were aggregated into an index of socio-economic determinants of agriculture. Overall, the final index values revealed spatial differences which enabled a certain separation between the eastern, central and western parts of the Romanian Plain: socio-economic favourability for agriculture in the central and, to some extent, in the eastern parts and a significantly reduced favourability in the western area. The current research could become an important step for in-depth assessments of environmental and socio-economic determinants of agriculture, developing strategies and supporting policies at different spatial scales.
\end{abstract}

Key Words: index of socio-economic determinants, agricultural development, regional disparities, Romanian Plain.

\section{Introduction}

Agriculture plays a central role for food security and sustainable development (Smith et al. 2014) being one of the foremost land uses in Europe (Rounsevell et al. 2003). According to CORINE Land Cover, cropland (including both arable land and permanent crops) covered, on average, some $24.8 \%$ of the total area of the EU-27 in 2012. Romania has a significant share of agricultural land (over 60\%), among the highest in the EU. As they are positioned at the interface between ecosystems and society (Olesen and Bindi 2002), the agricultural systems are subject to continuous evolution and change as a result of a range of global and local driving forces. To that, agricultural, environmental and rural development policies designed to contribute to the sustainability of agricultural systems (Van Ittersum et al. 2008) are added. The management of agricultural land has profound impacts on the quality of the environment through nutrient dynamics, water resources and biological diversity (Rounsevell et al. 2003).

Over the past decades, European landscapes have experienced rapid changes in agricultural land use in relation to the progress in technology and management driven by socio-economic and political forces (e.g. Common Agricultural Policy - CAP, enlargement of the European Union, technological change) and biophysical factors (e.g. climate change) (Rounsevell et al. 2003, Verburg et al. 2004). Agricultural land is the foremost resource to be engulfed by urban development which is the main land consumer (Barnes et al. 2001). The consequences of this land use transition involve social changes (e.g. life quality and lifestyle, segregation), environmental impacts (e.g. surface sealing, emissions, ecosystems fragmentation), and economic changes (e.g. distribution of production, land prices) (Patacchini and Zenou 2009). 
These changes are affecting the structure of agricultural production and spatial patterns of agricultural land use are expected to persist due to the changes in global trade, technology, demography and policies (Busch 2006). Thus, under the increasing demand for food and fibre, the change of consumption patterns and the use of agricultural resources (Gerbens-Leenes and Nonhebel 2005), the scientific interest in agriculture-related issues is becoming increasingly important and the addressed topics more diversified. Many studies have been concentrating on understanding (Smith and Bustamante 2014) and modelling (Lambin et al. 2000, Rounsevell et al. 2003, Rounsevell et al. 2005, Audsley et al. 2006, Temme and Verburg 2011, Meiyappan et al. 2014, Van Vliet et al. 2015) agriculture land use/cover changes, estimating crop productivity (Ewert et al. 2005), land management, drivers and consequences of agricultural land abandonment (Rey Benayas et al. 2007, Baumann et al. 2011, Renwick et al. 2013), the policies' impacts on agriculture (Mattison and Norris 2005, Van Meijl et al. 2006, Banse et al. 2011), the role of socio-economic factors and land degradation (Boardman et al. 2003). In addition, a large body of work has been devoted to understanding the impacts of climate change on agriculture and farmer's perceptions and preparedness (Olesen and Bindi 2002, Smit and Skinner 2002, Morton 2007, Bindi and Olesen 2011, Olesen et al. 2011, Bălteanu et al. 2013, Sima et al. 2015, Bennetzen et al. 2016, Niles et al. 2016).

Land use decisions, which include agriculture, mainly depend on the environmental conditions, but they represent also the effects of the socio-economic and policy forces (Fraser and Stringer 2009). Moreover, in order to improve the understanding of the causes and effects of land-use change and to support sustainable landscape development, recent studies integrated socioeconomic and bio-physical factors (Mottet et al. 2006). Therewith, the importance of assessing determinants in agriculture was already argued in the scientific literature. The socio-economic changes which followed the collapse of the communist system have had a deep impact on the labour markets in Central and Eastern European countries (Tocco et al. 2014) which have also affected the Romanian labour market, including the employment in agriculture (Ciutacu and Chivu 2007, Mateoc-Sîrb et al. 2014, Mocanu 2015). Also, aging of the rural population (Serban 2012, Chirițescu et al. 2015), migration of young people (lanoș 1998, Szocs et al. 2015), the role of rural infrastructure (Binswanger et al. 1993, Pinstrup-Andersen and Shimokawa 2007, Shimokawa 2007), transport and services (Lako 1990) have been listed among the foremost indicators in determining agricultural development.

Agriculture is a major economic branch in Romania. Within the EU-27, 70\% of the agricultural labour input is concentrated in six countries: Poland, Romania, Italy, Spain, France and Germany; Poland and Romania alone represent $37 \%$ of the total. Under the social and economic transformations subsequent to the fall of communism (1989), agriculture in Romania has undergone significant spatial and structural changes. The transition (1990-2003) and posttransition (2003-2007) periods have marked a changeover in the economy from the old centralised system to the free market system. In agriculture, the transition from state and collective property to private ownership through de-collectivisation and privatisation had a particular impact on crop growing and land fund (Popovici et al. 2016). Moreover, through the reconstruction and consolidation of the right of property over the land under certain "Land Laws" (e.g. Law 18/1991), the land was subject to excess fragmentation (big farms gave way to small, peasant-type family farms), degradation of the productive quality of agricultural terrains (Bălteanu and Popovici 2010, Popovici et al. 2013, Popovici et al. 2016) and land abandonment (many arable lands and permanent crops) giving place to the conversion to other land use categories (e.g. residential, commercial, warehouses) under urban development processes (Grigorescu et al. 2015). Hence, under these complex changing conditions of the post-communist period, identifying, selecting and integrating socio-economic indicators is an important step in understanding the role of the socio-economic factors of agricultural development in the most important agricultural region in Romania, the Romanian Plain. 


\section{Methodology}

\section{Study area}

The Romanian Plain, also known as the Lower Danube Plain, is located in the southern and south-eastern part of Romania, stretching between the Danube in the south and the Getic Piedmont, the Curvature Subcarpathians and the Moldavian Plateau in the north. It covers 52 $600 \mathrm{sq} . \mathrm{km}$, being the largest plain area and the main agricultural region of Romania (Bălteanu 2016). This relief unit is characterized by a significant agricultural potential which is influenced, in particular, by the specific natural conditions: high percentage of arable land $(80-90 \%$ of total agricultural surface), the existence of large areas covered with high fertility soils (e.g. chernisols, brown and reddish-brown argilluvic), and relative homogeneity of morphohydrographic and climate conditions (Fig. 1).

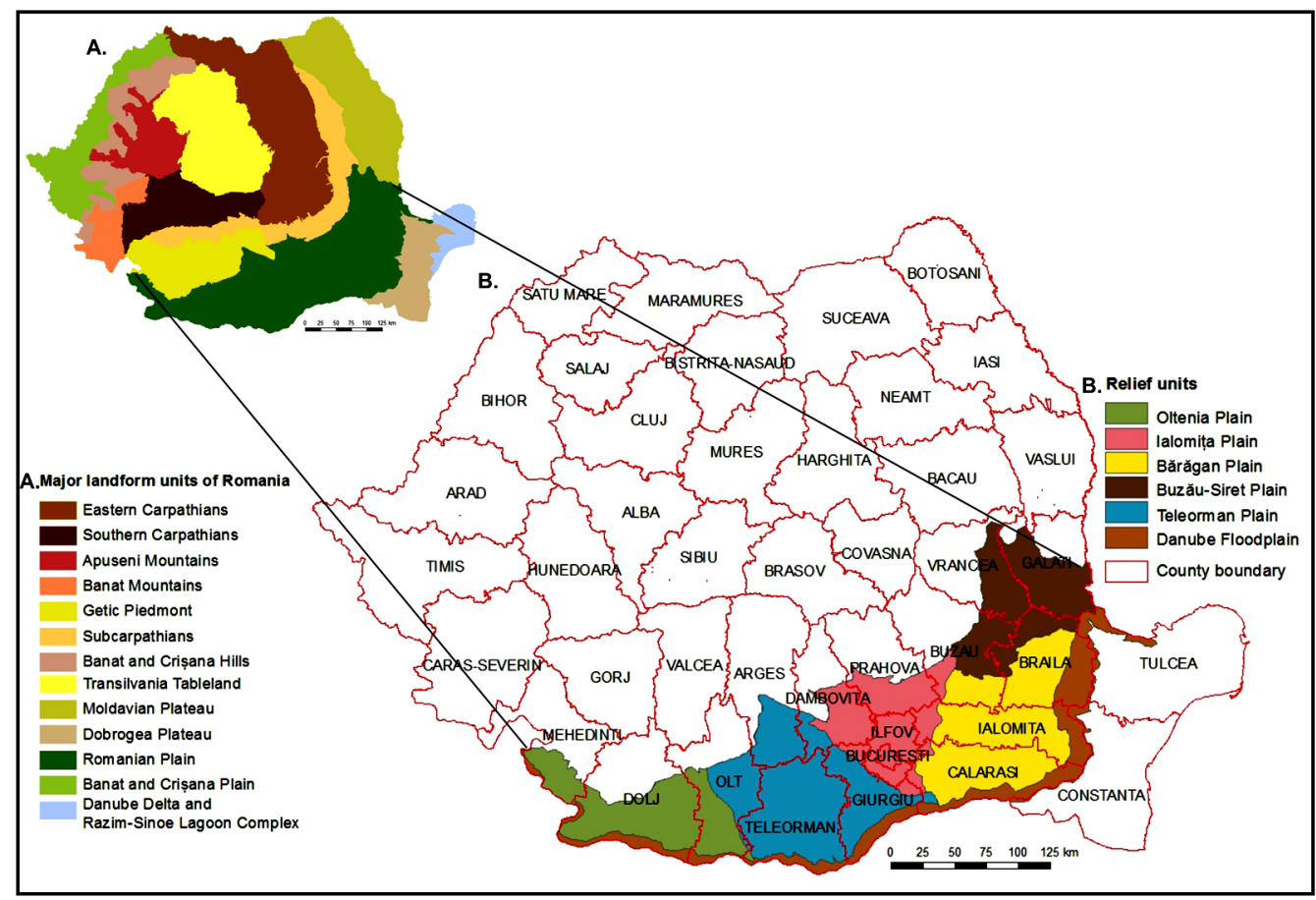

Fig. 1 - Location and main relief units of the study area

In 2013, the agriculture of the Romanian Plain had a significant contribution to the total crop production of Romania $(64 \%$ of the total sunflower production, $58 \%$ of the total wheat production and $46 \%$ of the total maize production). The plant production was strongly influenced by the socio-economic and political conditions of the post-communist period. This influence mainly depended on the farming practices (e.g. the absence of functional irrigation systems, fewer natural and chemical fertilizers, poor mechanization), inadequate farm structure, agricultural policies, and besides, the intensification of climate change-induced extreme phenomena (drought, desertification, hail-storms and floods), annually affecting ever larger cultivated terrains. 


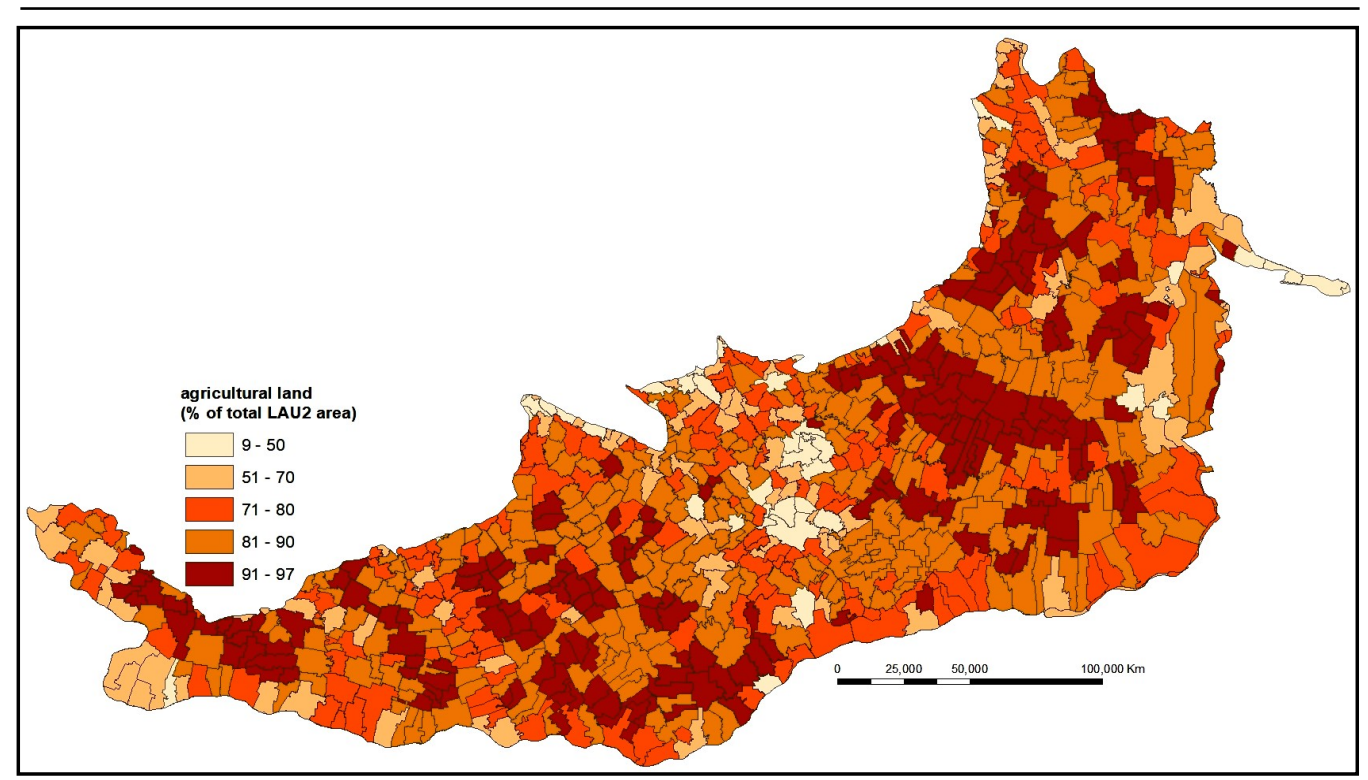

Fig. 2 - The share of agricultural land

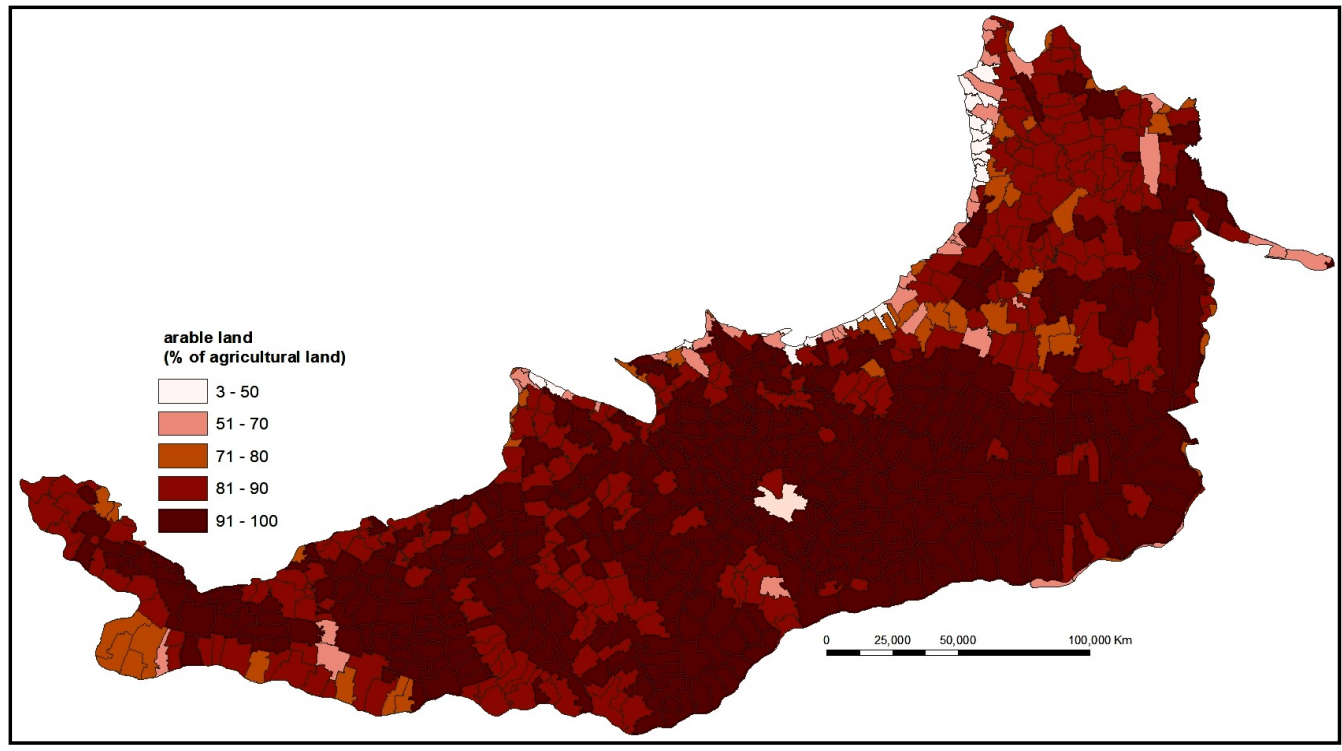

Fig. 3 - The share of arable land

In over $60 \%$ of the LAU2 overlapping the study area, the share of agricultural land often exceeds $80-90 \%$ of the total surface, mainly concentrated in the eastern (e.g. Bărăgan Plain), central (e.g. Teleorman Plain) and north-western (north of Oltenia Plain) (Fig. 2) parts.

Arable land is the main agricultural land use category, having a share of over $90 \%$ of total 
agricultural land in almost $50 \%$ of localities and between $80-90 \%$ in $30 \%$ of total number of localities (Fig. 3).

\section{Socio-economic assessment of agriculture development}

The current study relies on the statistical data provided by the Population and Housing Censuses 2011 (National Institute of Statistics 2011), as well as on the TEMPO-Online time series (National Institute of Statistics 2015) available at LAU 2 (the lowest level of administrative-territorial units in Romania).

In order to assess the socio-economic determinants for the development of agriculture in the Romanian Plain, the authors selected 9 statistical indicators based on several research papers, reports and studies. The Green Paper. Regional Development Policies in Romania (1997) realised a hierarchy of counties using the global index of development based on 17 indicators (e.g. the roads density, the railways density, the vitality index). The UNEPA report (Preda 2003), focused on issues regarding the socio-economic development and population in order to understand the importance of contextualizing thematically and territorially the indicators. The highest share of some indicators (e.g. employment in agriculture) was highlighted by MateocSîrb et al. (2014) mainly as a result of workforce redundancies from the other sectors of the urban economies then the needs of agriculture, and by Ciutacu and Chivu (2007) in relation to the small traditional households, small farms and subsistence agriculture.

In the study on land grabbing in Romania, Szocs et al. (2015) used indicators such as the share of aged population and the migration of young people to explain the underdevelopment of rural areas. Moreover, understanding the relationships between rural infrastructure and agricultural development is essential in supporting growth and poverty reduction, especially in predominantly agricultural areas or low-income countries (Pinstrup-Andersen and Shimokawa 2007). Thus, several studies have emphasized the role of rural infrastructure in increasing farmers access to input and output markets (Binswanger et al. 1993), in stimulating the rural economy and the revitalization of small towns (Antle 1984), in increasing the consumer's demand in rural areas, and in facilitating the integration of less-favoured rural areas into the national and international economies (Fan et al. 2002, Mundlak et al. 2002, Fan and Zhang 2008). Also, the transport infrastructure and services are crucial for agriculture, being important for all actors along the agricultural value chain. In opposition, the lack of quality infrastructure and efficient transport can be an obstacle for small-scale producers in obtaining the necessary inputs and marketing their crops (Lako 1990). Moreover, Michalek and Zarnekow (2012) constructed a multi-dimensional (composite) index to measure the overall level of rural development and quality of life in the individual rural regions of Poland and Slovakia based on socio-economic, environmental, infrastructural and administrative indicators/variables.

Thus, the 9 statistical indicators (supported by 18 statistical variables) at LAU2 level selected for the current study were: agricultural surface (AGR_LAND), labour renewal index (LAB RENEW), economically active population (EC_AC_POP), employment in agriculture (EMPLOY_AGR), economic dependency rate (DEPENDEC), the vitality index (PEARL), young labour (YŌUNG_LAB), the female population (FEMALE) and roads and railways density (TRANSP). All these indicators were aggregated into an index of socio-economic determinants of agriculture (SOC_EC_DET_AGR).

The main factor which influenced the selection process was the availability of the statistical variables used for the computation of the indicators. Also, the local territorial level taken into consideration to assess the influence of each socio-economic determinant on agriculture diminishes the possibilities of selection because some of the indicators, despite their usefulness for the proposed objective, are available only for the upper territorial level. 
Given that the variables of the statistical indicators were calculated using different measurement units, the current analysis required normalisation procedures. The normalised value of the statistical indicator " $X$ " for the "i" LAU is $X_{s i}=\left(X_{i}-X_{\min }\right) /\left(X_{\max }-X_{\min }\right)$, where $X_{i}$ is the absolute value of the statistical indicator " $X$ " for the LAU " $i$ ", $X_{\max }$ is the maximum value of $X$ indicator and $X_{\min }$ is the minimum value of the $X_{i}$ indicator. The index of socio-economic determinants of agriculture was computed as Hull Score of the normalised values of the selected indicators. The Hull Score is calculated as the sum of the direct (,+") or reverse relation (,,-") of each statistical indicator in relation to the development process (lanoş 2000):

SOC_EC_DET_AGR $=50+14^{*}($ AGR_LAND + LAB_RENEW + EMPLOY AGR +
EC_AC_POP + PERAL + YOUNG_LAB + TRANSP - DEPENDEC - FEMALE $) / 9$

Each indicator, equally weighted in the final index, was individually assessed and displayed in GIS format in order to understand the influence of each socio-economic determinant on agriculture. As a result, the computation of the final index helped identifying the areas most favourable or unfavourable to agricultural development in the Romanian Plain.

\section{Results and Discussion}

The socio-economic determinants have significantly influenced agriculture over the last decades. Besides agricultural land use (agricultural land) which represents the support land resource for the development of agriculture, the demographic and socio-economic variables (e.g. young labour force, employment in agriculture, economic dependency rate, road and railway density) were also considered essential through their influence on agriculture.

The agricultural land represents the foremost land use resource for agriculture, especially since 1829 when, following the treaty of Adrianopole that liberalized trade with cereals and wood, the Romanian Plain become one of the most important agricultural regions in Europe. However, during the past decades, the major spatial and functional transformations of the postcommunist period have turned the region into one of the most vulnerable to extreme weather phenomena (e.g. dryness and drought, heavy rainfall) leading to the severe degradation of agricultural land with direct impact on the crop production, human health, and rural welfare (Dumitrașcu et al. 2018). In addition, this land use category has been subject to significant transformations under the impact of urban development (urbanization, suburbanization) or industrialization (Grigorescu and Kucsicsa 2017), but also under the extensification/ intensification of farming. A higher demand for food and further increases in the productivity of crops are likely to have significant impacts on the agricultural land use (Ewert et al. 2005). Thus, yields increases are regularly obtained through agricultural land intensification, one of the most significant forms of land-use/cover changes (Lambin et al. 2000).

The Romanian Plain has important land resources ( 0.6 hectares of agricultural land and 0.5 hectares of arable land per capita). The national average is 0.68 ha of agricultural land per capita and 0.43 ha of arable land per capita. At the LAU2 level these values vary significantly, from 1-5 ha per capita (most commonly) to 10 hectares per capita, but the most frequent values fall between 1 and 5 hectares per capita. The exception is the Frecăţei commune (Brăila County), where agricultural, respective arable land per capita reach 25 ha due to the drainage and embankment of "Balta Brăilei" (an extended floodplain area between the two arms of the Danube River in the eastern part of the Romanian Plain) and its conversion into farmland "Insula Mare a Brăilei" (Fig. 4). 


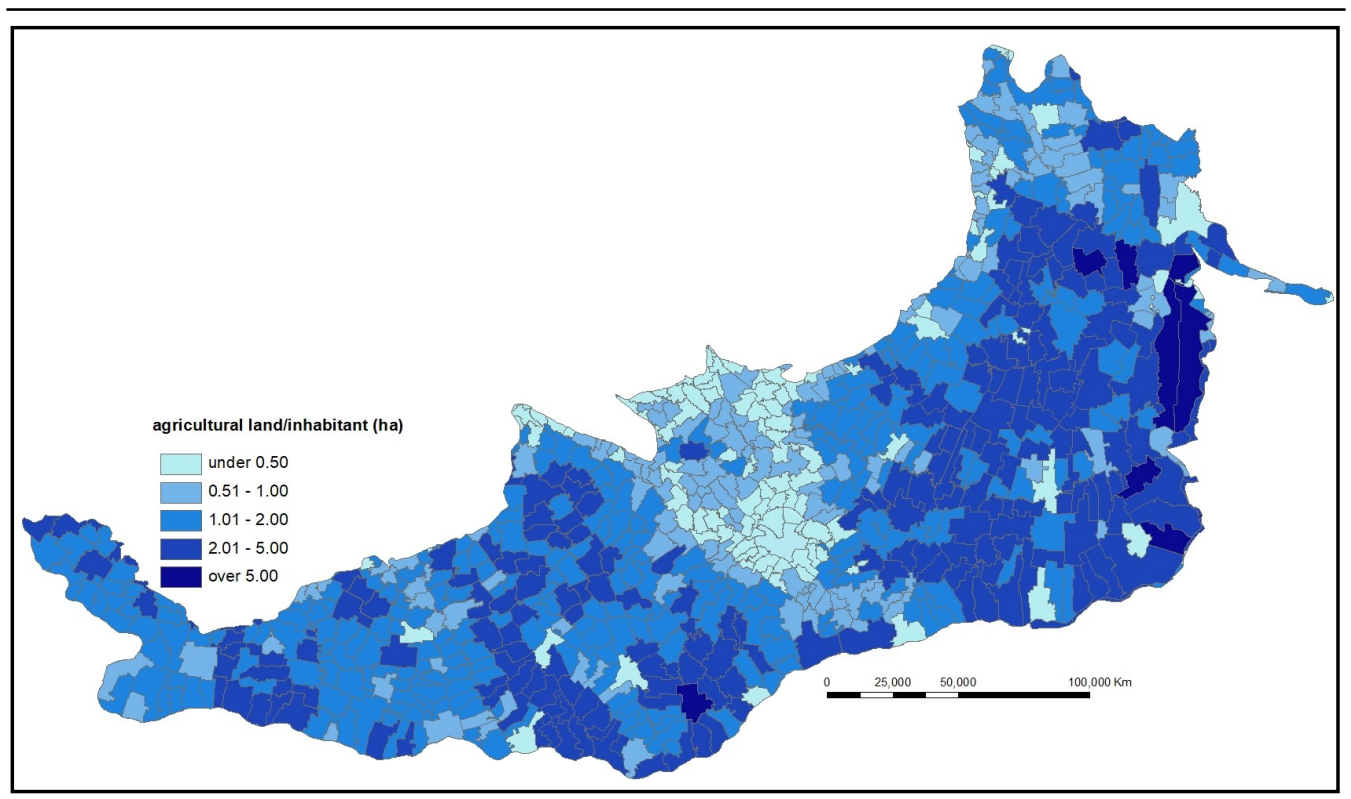

Fig. 4 - The share of agricultural land per capita

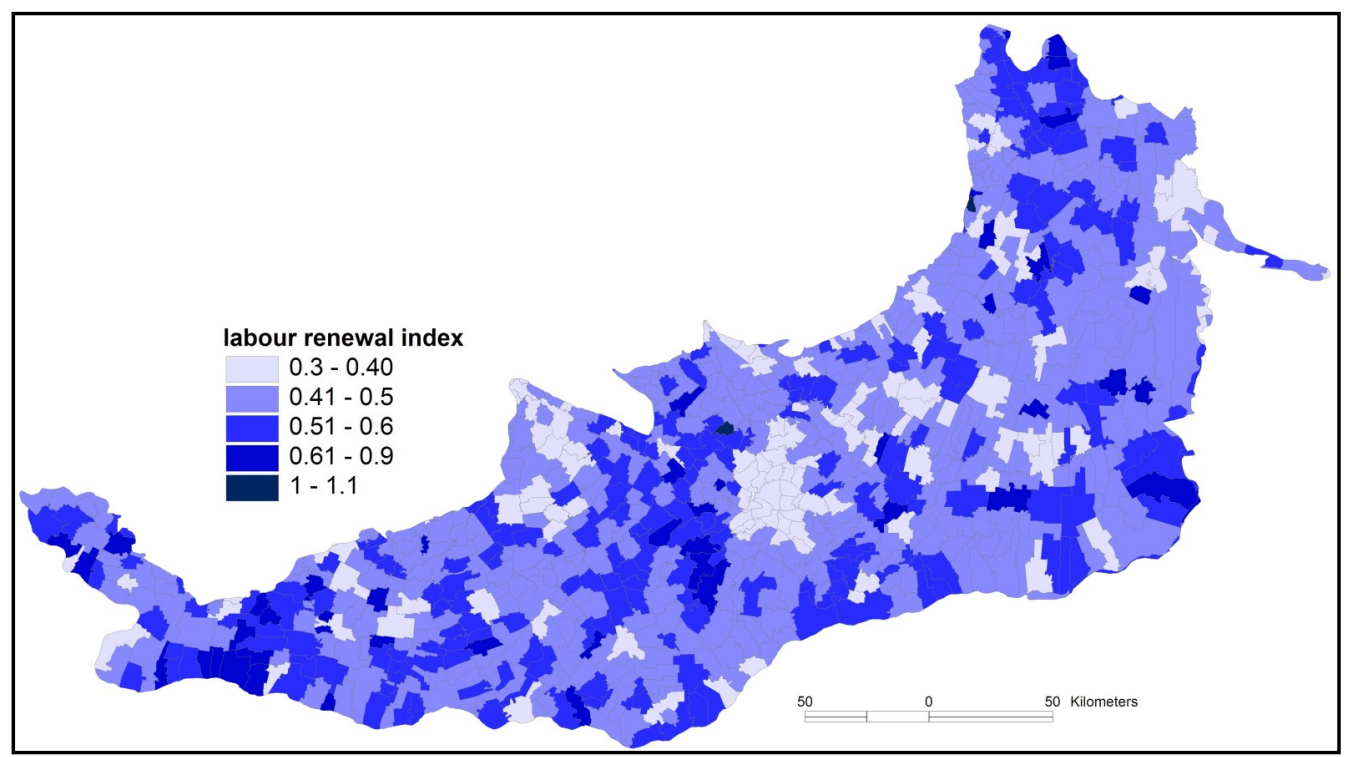

Fig. 5 - The labour renewal index

The labour renewal index, or the labour substitution index (Nancu et al. 2015) closely linked to the age structure of the labour force, is calculated as the ratio between the population aged 15-29 and 30-44. The evolution of the index is almost similar to that of the 15-29 age group, being correlated with the birth rate of the last three decades. Generally, when the index is below unity, the continuation of creative and productive workforce and, implicitly, the 
development of the economy and society are not secured (Mihăescu 2001). Generally, the highest values of the labour renewal index are registered in the rural areas (e.g. Slobozia Bradului, Vrancea County, and Cojasca, Dâmboviţa County with over 1.0). Also, a concentration of LAU2 with very high values $(0.6-0.8)$ is found in the south-eastern (e.g. Catane, Cerăt, Lipovu, Urzicuța in Dolj County), central (e.g. Buzescu, Plopii-Slăvitești, Lisa in Teleorman County) and north-eastern (e.g. Tâmboiești, Ploșcuteni in Vrancea County and Tichilești in Brăila County) parts of the Romanian Plain. These areas overlap the most important agricultural areas (e.g. Oltenia Plain, Bărăgan Plain) also providing most of the workforce for agriculture (Fig. 5).

Ilfov County (under 0.3 in Corbeanca, Berceni, Voluntari, Otopeni, Bragadiru) and the city of Bucharest (0.4) register the lowest values of the renewal index mainly in relation to the economic profile of Bucharest which holds $83 \%$ of the service sector of all active enterprises and the relocation of some companies following the deindustrialization of the capital-city (Bălteanu et al. 2016). The reduced values explain the limited productive potential of the region for agriculture. However, the surrounding areas of Ploieşti and Piteşti are able to supplement the workforce needed through the positive migratory balance (Bunea 2011, 2012).

Lower values (0.3-0.4) are also recorded in the LAU2 located in the surroundings of the important cities (e.g. Galaţi, Piteşti, Ploieşti, Craiova) mainly in relation to the migration of young workforce to the polarising cities. Overall, the largest extent of LAU2 with values below unity suggests the low capacity of the study-area to maintain its demographic and productive force, mainly because of population ageing and of in- and out-migration (both involving young and adult workforce) (Fig. 5).

The economic dependency rate expresses an employee's upkeep of another person who does not discharge a remunerative activity. This indicator is calculated as number of nonoccupied persons (inactive and unemployed)/100 occupied persons. Generally, the economic dependency rate varies between $50 \%$ and $550.3 \%$, the territorial differences being deeper than in the urban area. Almost half of total LAU2 totally or partially overlapping the study-area record economic dependency rate values below the national average of $136 \%$ (in 2011). As a result, within these communities, the employed population (as factor of production) have the capacity to create incomes, goods and services both for themselves and for the unemployed, thereby sustaining directly, or indirectly (through redistribution), the entire population of each LAU2. The lowest values of economic dependency rate (50-136.1\%) are recorded by the small towns (e.g. Popeşti-Leordeni, Pantelimon, Bragadiru in Ilfov County) and the rural settlements (e.g. Chiajna in Ilfov County) located in the suburbs of Bucharest. Besides, in the central and eastern parts of the Romanian Plain, two extended areas with low economic dependency rate values are found: Teleorman Plain (e.g. Ciuperceni, Necșești, Uda-Clocociov in Teleorman County; Popești, Rociu in Argeș County; Valea Mare, Slobozia Moară, Vișina, Lungulețu in Dâmbovița County) and north-west of Bărăgan Plain and Buzău-Siret 'Plain (e.g. Nana, Tămadău Mare, Căscioarele in Călărași County; Râmnicelu, Victoria in Brăila County; Movileni, Corod in Galați County) (Fig. 6).

The highest dependency rates (over 298.5\%) are recorded in two distinctive areas: Oltenia Plain, mostly in the Dolj County (e.g. Cerat, Catane, Ghidici, Măceșu de Jos) and south-east of Bărăgan Plain, i.e. Balta lalomiţei, covering the LAU2 included and overlapping Constanța (e.g. Gârliciu, Oltina, Crucea, Ciobanu) and Călărași (e.g. Modelu, Dragalina) counties. Here, the figures are related to the population aging and the high unemployment rates.

Among the urban areas, the economic dependency rate is rather small to medium, varying between $101.2 \%$ and $272.6 \%$. The highest values being characteristic to the small towns located in Olt, lalomiţa, Călăraşi, Giurgiu counties (e.g. Drăgăneşti-Olt, Corabia, Potcoava, Budeşti, Bolintin Vale) and the lowest to those located in Ilfov county (Fig. 6). 


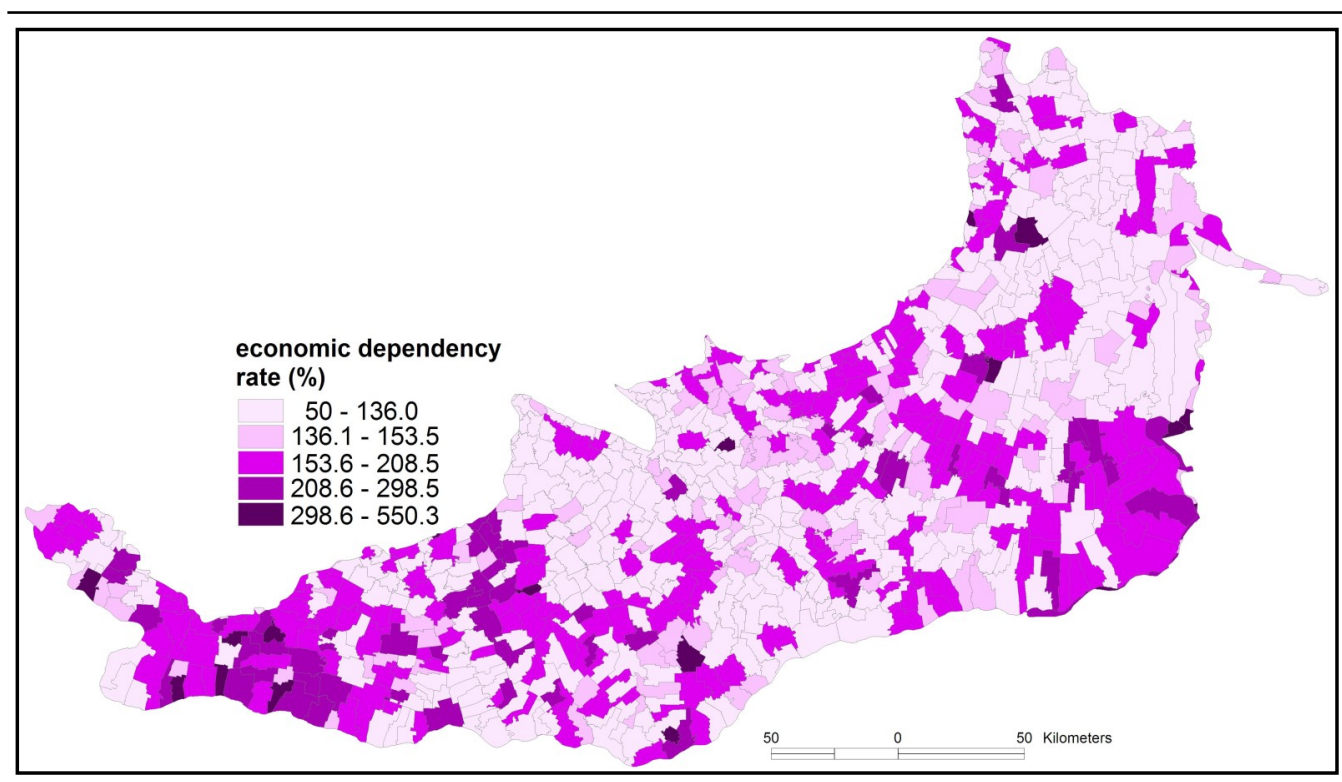

Fig. 6- The economic dependency rate

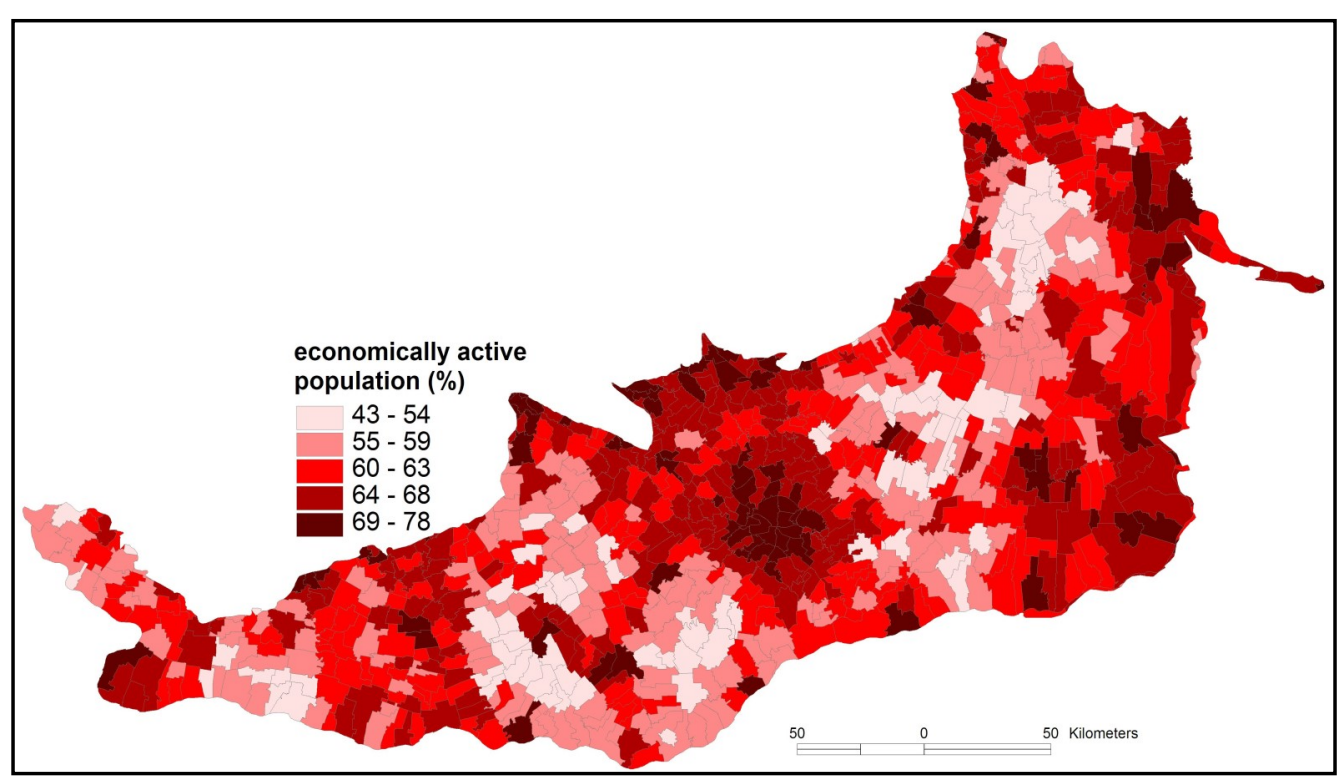

Fig. 7 - The economically active population

The economically active population was calculated as the ratio between the active (aged 1564 years) and the total population (Mihăescu 2001), thus the dynamics of this indicator is related to the dynamics of the total population. On the other hand, it has been demonstrated that population ageing (population above 64 years old) has a strong influence on the observed outflow of agricultural labour force (Tocco et al. 2014). In 2015, the economically active 
population in the Romanian Plain accounted for 4.9 million people, nearly $72 \%$ in the urban areas (close to the national rate of $70.3 \%$ ), and $62 \%$ in the rural areas.

Although the most numerous workforce (over 69\%) is concentrated in the Capital City, in the county-seats (e.g. Slatina, Slobozia, Focșani, Brăila, Alexandria, Târgoviște, Pitești, Craiova), in the small towns (e.g. Popeşti Leordeni, Pantelimon and Bragadiru, Bascov) and in some rural settlements located in the surroundings of Ploiești (e.g. Bucov, Florești), Târgoviște (e.g. Ulmi, Văcărești, Dragomirești), Pitești (e.g. Bascov, Bradu) or Galați cities, the highest concentration of economically active population is in Ilfov county (surrounding the city of Bucharest). Generally, the high values of the workforce rate of the total population are correlated with the high and positive values of the natural balance and vitality index (e.g. the rural settlements from the proximity of Galaţi City) or with the positive level of the migratory balance (e.g. in the surroundings of Bucharest, Pitești, Ploiești) (Fig. 7).

Large areas of the Romanian Plain recorded low and very low values of the economically active population (under $60 \%$ ) in relation to the population shrinkage, mainly triggered by a negative natural balance and population migration.

The employment in agriculture is one of the main indicators supporting the development of agriculture which has been dramatically declined due to the massive transformations occurred in the agricultural sector both as effects of the Common Agricultural Policy on intensive agriculture and a sustained migration to the urban areas in search for well-paid jobs (Ciutacu et al. 2015). Moreover, agriculture has become dominated by self-employment and low revenues largely generated from subsistence farming (Popescu 2016). In some cases, the inter-sectoral movements of labour included the movement of employment from agriculture to the industrial or services sector on the one hand, and to unemployment or out of the labour force on the other hand (Tocco et al. 2014). However, in many rural areas agriculture absorbed the unemployed people from industry who couldn't be taken over by the service sector (Popescu 2016). This phenomenon can be associated with retirement and unemployment, agriculture becoming a sink for the less-skilled and unemployed population, providing especially a source of income for the elderly (Tocco et al. 2014).

In the study area, 1.07 million people are employed in agriculture (26.8\% of the total employed population), which is significantly higher than the Europe average of $5.2 \%$. The highest values (over $80 \%$ ) are registered in the rural settlements located in south-western and eastern parts of the Romanian Plain where the most important agricultural areas of Romania are located. Thus, in the south-west (Oltenia Plain) the largest number of LAU2 with high employment in agriculture are grouped, mainly in Olt (e.g. Izbiceni, Cilieni, Giuvărăști), Dolj (e.g. Desa, Motăței, Ghidici), and Mehedinți (e.g. Dârvari, Corlațel, Vlădaia) counties.' In the east (Bărăgan and Buzău-Siret Plains), another grouping of high employment in agriculture includes several of the rural settlements in Brăila (e.g. Victoria, Vișani, Frecăței, Râmnicelu) and Buzău (e.g. Glodeanu Sărat, Vâlcelele) counties (Fig. 8).

The lowest values (under 20\%) are characteristic for the very large, large, medium-sized and small cities and towns (e.g. Bucharest, Craiova, Galați, Brăila, Ploiești, Buzău, Slobozia, Hârșova) and for some urban and rural LAU2 located in the surroundings of Bucharest, Galaţi, Brăila and Constanţa cities, being more attractive for industrial or tertiary activities.

An important aspect of the employment in agriculture is the self-employment. In 2009, the self employment in the total employment in Romania was considerably higher than the EU-27 average. However, nearly $79 \%$ of this value was accounted by the small farmers (on 3.3 ha average size of the individual farm) that still practiced subsistence, or semi-subsistence farming, with little communication with the market (European Commission 2010). 


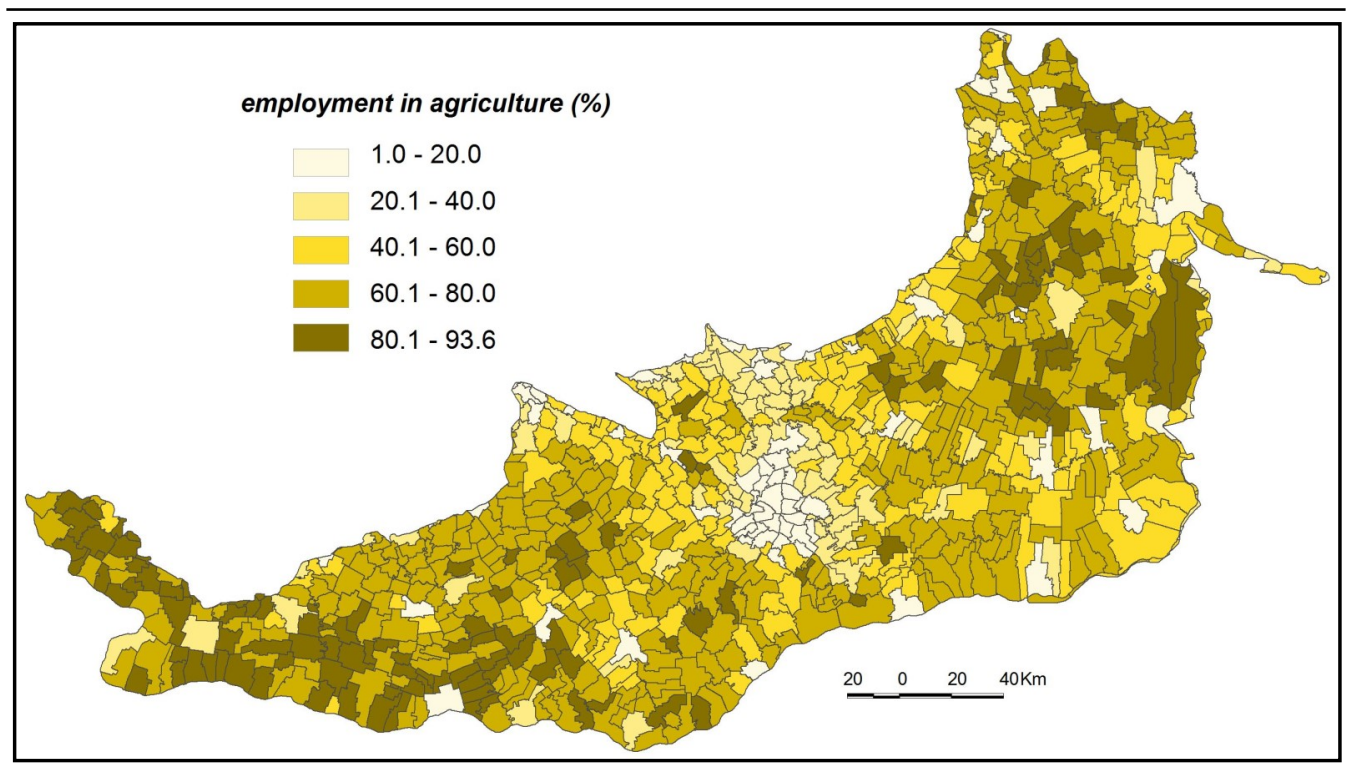

Fig. 8 - The employment in agriculture

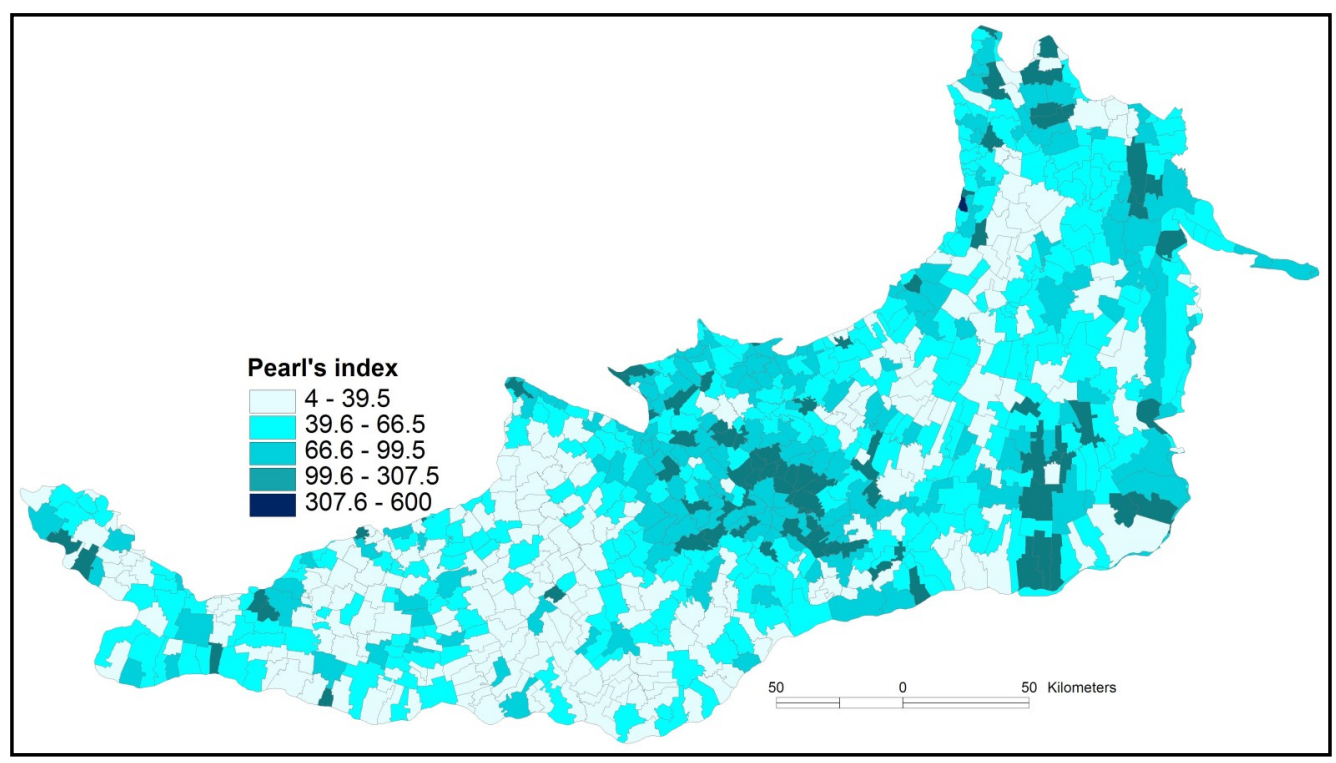

Fig. 9 - The Pearl's (vitality) index

The Pearl's index (vitality index) is the ratio between the number of live newborns and of deceased people over a certain period of time. Depending on the number of newborns (higher, lower, or equal to the deceased), the vitality index is lower, higher or equal to 100 . With index values near 100 , or equal to 100 , the population tends to become stationary, while when the index is above 100, there are more newborns than deaths and the population tends to increase 
(Vert 1995). Hence, it is an indicator of the self-renewal capacity of a population.

The vitality index in the Romanian Plain registers an average value of $72.6 \%$, under the national average $(78.05 \%)$. However, there are significant differences between the maximum $(600 \%$ in Slobozia Bradului, Vrancea County) and the minimum (4\% in Isvoarele, Giurgiu County) values. In almost $90 \%$ of total LAU2, the vitality index values are below $100 \%$, which can be related to the population shrinkage and the negative migration balance. In the settlements surrounding the city of Bucharest and in other rural and urban localities from the north-eastern and south-eastern parts of the Romanian Plain, the high values of the vitality index are coupled with the positive migration balance (Fig. 9).

The differences between the urban and rural areas are also important. Between 2011 and 2015, the total urban population of the Romanian Plain increased with 775014 inhabitants due to the positive migration and/or positive natural balances recorded by the different cities and towns. Thus, the urban areas register significantly higher values ( $90.3 \%$ of total LAU2) than the rural areas $(65.7 \%$ of total LAU2). However, the extreme values in the urban areas are recorded by the small towns, $307 \%$ in Țăndărei (lalomița County) and $40 \%$ in Dăbuleni (Dolj County). Among the rural settlements, only $8 \%$ recorded vitality index values above $100 \%$ in some LAU2 located in the surroundings of Bucharest (e.g. Ciorogârla, Cornetu, Afumați, 1 Decembrie in Ilfov County) or in the south-eastern (e.g. Drăgoești, Ograda, Mărculești in lalomița County and Tămădău Mare, Spanțov in Călărași County) and northern (e.g. Slob́ozia Bradului, Tâmboiești in Vrancea County; Smârdan, Ghidiceni, Vânători in Galați County) parts of the Romanian Plain (Fig. 9).

In the Romanian Plain, the young labour force, computed as the share of young population (aged 15-24) of the total active population (aged 15-64), is $17 \%$ on an average, slightly below the national value $(18 \%)$. However, there are significant differences between the rural and urban areas. Higher shares are registered in the large and very large cities (e.g. Bucharest, Craiova, Galați, Ploiești), while lower values are recorded in the small towns scattered throughout the study-area (e.g. Făurei, Căzănești, Vânju Mare, Piatra-Olt, Răcari, Amara). Generally, in the rural areas, only $39 \%$ of the young labour force is concentrated, mainly related to the low birth rates and out-migration which triggers population aging. However, in the rural areas, the highest values are found in the surroundings of Bucharest, Craiova, Galati, Pitești cities, while the lowest are registered in some small settlements with a reduced total population and labour force e.g. Cetalachioi (Tulcea County), Ciorcârlia, (lalomița County), Răsmirești (Teleorman County) (Fig. 10).

The spatial differences can be explained in relation to the socio-economic profile of the settlements, as well as to the structure and trend of population. Higher shares (over 22.9\%) are concentrated in the central part of the Romanian Plain especially in Teleorman (e.g. Purani, Poeni, Lunca, Mereni) and Dâmbovița (e.g. Cojasca, Mănești, Hulubești, Potlogi) counties. Also, extended areas with significant shares of young labour force are found in the eastern parts of the Romanian Plain in Călărași (e.g. Sărulești, Roșeți, Gălbinași, Curcani), lalomița (e.g. Borănești, Bordușani, Ograda) and Brăila (e.g. Tichilești, Berteștii de Jos, Grădiștea) counties. In the small towns of Țăndărei, Fundulea, Boldești-Scăieni, Budești and some rural settlements (e.g. Slobozia Bradului in Vrancea County and Cojasca in Dâmbovița County), the high shares of young labour force are related to the high shares of Roma population.

The share of female population ( $\%$ female of total population). The continuous deindustrialisation processes and the expansion of the service sector in Europe have generated changes related to the labour demand, thus women have become more present and active in the labour market (Palomba and Kotowska 2003). In Romania, the feminisation trend is more evident in the urban settlements (52.6\%), following both the national (Urucu and Nancu 1992, 


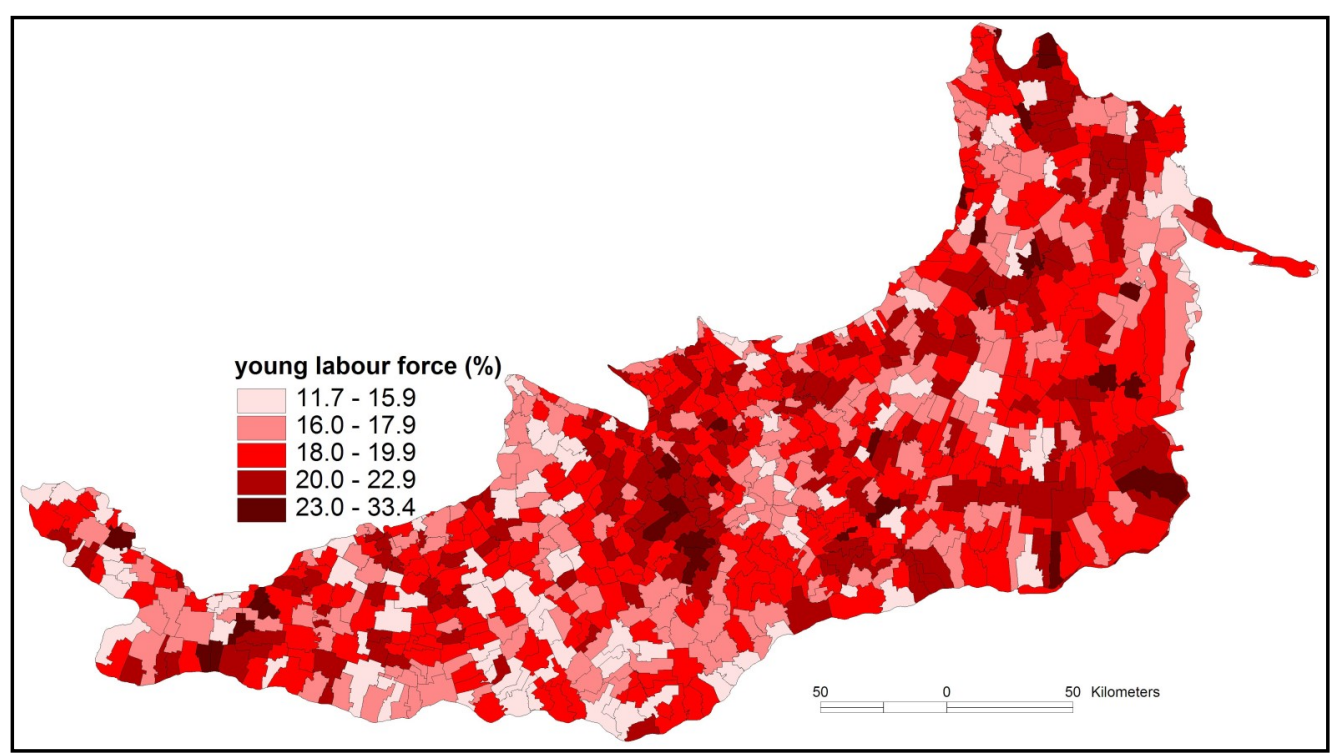

Fig. 10 - The young labour force

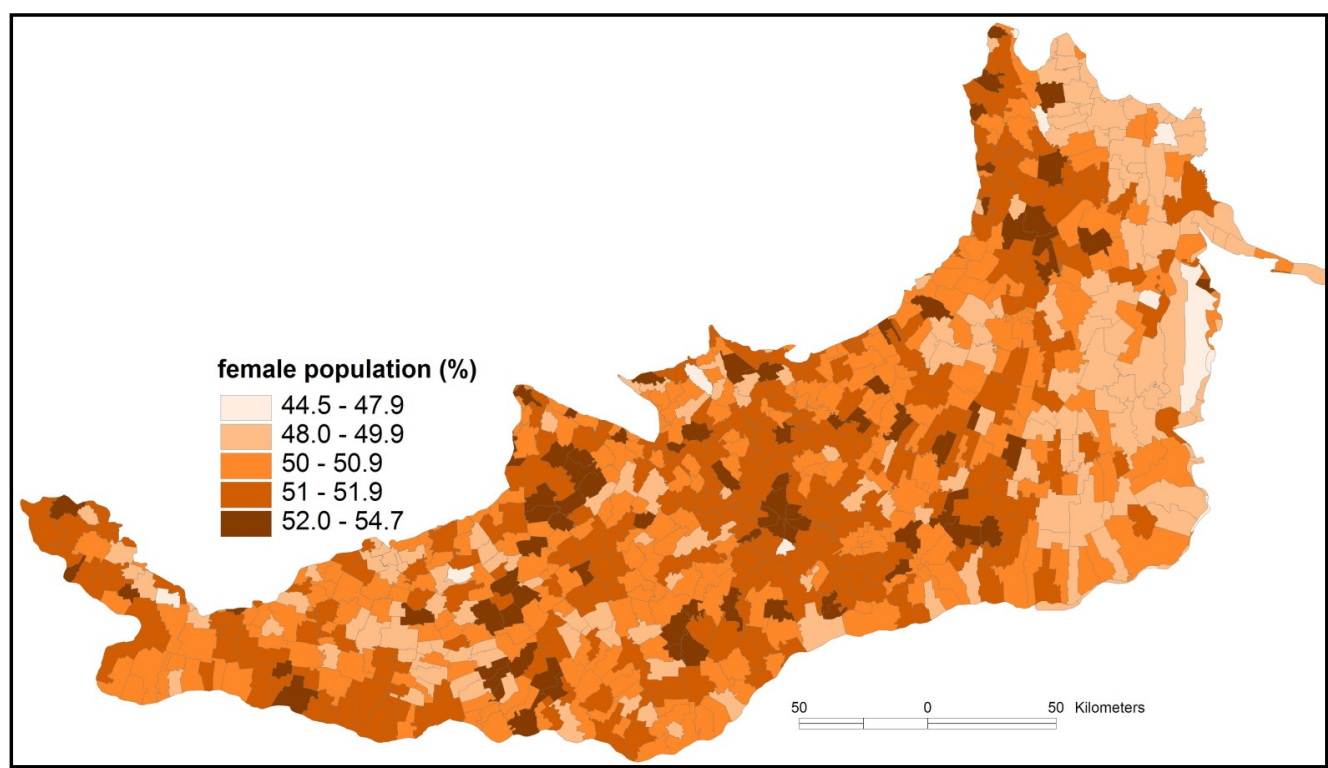

Fig. 11 - The share of female population

Nancu and Persu 2004) and the international (Tacoli and Mabala 2010, Tacoli 2012, Chant 2013) tendency. In the Romanian Plain, the share of female population is nearly $52 \%$, slightly above the national value $(51 \%)$. The rural areas register $50.6 \%$ female of the total rural population. The feminisation of Bucharest City is reflected by the highest share of female 
population $(54.7 \%)$. The lowest values are grouped in two main areas located in the eastern (e.g. Tichilești, Frecăței, Însurăței in Brăila County, Scânteiești, Movileni, Smârdan in Galați County) and central-western (e.g. Unirea, Apele Vii in Dolj County, Izvoarele, Redea in Olt County) parts of the Romanian Plain, where the values are well below 48\% (Fig. 11).

The road and railway density. Generally, in the Romanian Plain the roads and railways density is of $1.48 \mathrm{~km} / \mathrm{km}^{2}$. In the urban areas, this value is almost double $\left(2.66 \mathrm{~km} / \mathrm{km}^{2}\right)$, while in the rural areas it is considerably lower $\left(1.01 \mathrm{~km} / \mathrm{km}^{2}\right)$. Almost $76 \%$ of the total settlements located in the rural areas have road and railway density values below the average. However, the transport infrastructure, especially the railway network, follows the main river valleys which cross the plain and the road and railway density is higher in the central part of the study-area and along the contact between the Romanian Plain and the Subcarpathian hilly area (Fig. 12).

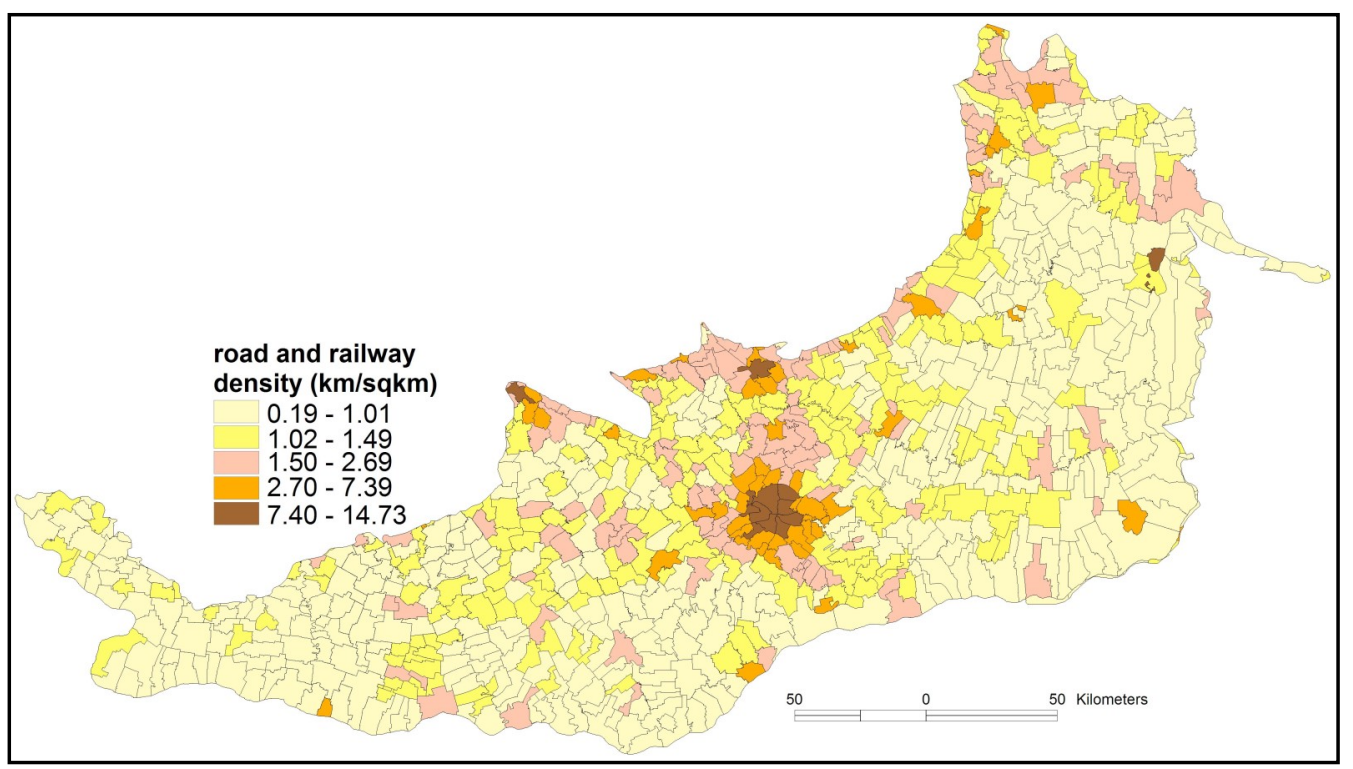

Fig. 12 - The road and railways density

Even if the roads density is higher than the railways density $\left(0.33 \mathrm{~km} / \mathrm{km}^{2}\right.$ vs. $\left.0.12 \mathrm{~km} / \mathrm{km}^{2}\right)$, in the eastern and central parts of the Romanian Plain, the railways infrastructure complements the transport network. In the western part of the study-area (Oltenia Plain) the road density is low, not being balanced by the railway network. Nevertheless, in this area, the Danube River might have an important role since the transport of agricultural goods on barges along the river is a more appropriate option to the road or rail, thus the links between these types of infrastructure with the waterways are very important. Out of the 28 ports located along the Danube and the waterway channels, 18 have both road and railway connections, thus enabling effective intermodal transportation of the agricultural goods, especially since the volume of agriculture goods on the Danube River prevails with nearly 34\% (Intermodal Transport Strategy for 2020-2011).

Following the assemblage and interaction of the selected nine indicators, the index of socioeconomic determinants (SOC_EC_DET_AGR) has resulted. Based on its computation and spatial distribution, areas more or less favourable for the development of agriculture have been delineated. The strong agricultural legacy of the region, the long standing economic and social 
underdevelopment and high level of rurality (Popescu 2016) had determined several development restrictions, especially in some areas with poor infrastructure and limited labour resources. The results of the index of socio-economic determinants spatially delineate areas with very high (>52), high (51-51.9), medium (50-50.9) and low (<49.9) potential development of agriculture (Fig. 13).

The highest values of the socio-economic determinants index are registered by Bucharest and by some large and medium-sized towns (e.g. Craiova, Focșani, Adjud, Târgoviște, Slatina), mainly triggered by the high values of some indicators (e.g. labour renewal index, economically active population or roads and railways density) thus highlighting the socio-economic likelihood of the human resource to sustain agriculture. The territorial clustering of the highest index values located in and around large cities is linked with the role they play as important consumers of agriculture products. Also, these values stream from a specific historical and cultural background (e.g. the Bulgarian immigrants from the south of Danube whose main occupation was vegetable growing and their establishment in different localities of the Romanian Plain), which was perpetuated and in some cases now integrated with the new socio -economic conditions in the studied area (Matca, Galați County). Herewith, the highest values are also recorded in some rural and urban settlements located in llfov (e.g. Jilava, 1 Decembrie, Voluntari, Chiajna, Măgurele, Chitila), Brăila (e.g. Tichilești, lanca), Dâmbovița (e.g. Cojasca, Niculești, Vișina), Galați (e.g. Smârdan, Schela), Giurgiu (Grădinari, Cosoba, BolintinVale), lalomița (e.g. 'Tăndărei, Fetești), and Călărași (e.g. Ștefan cel Mare, Fundulea, Gălbinași) counties. High and medium values are the most widespread throughout the entire Romanian Plain, with extended areas in the Dâmbovița, Arges, Galați, Buzău, lalomița and Călărași counties. There, some of the indicators with positive influence on the final index (e.g. agricultural land, young labour, economically active population) registered high values and, concurrently, the indicators with reverse influence on the final index (e.g. economic dependency rate, female population) had values close or below the national average. The index of socio-economic determinants of agriculture registered the lowest values in an extended area located in the western (e.g. Oltenia Plain, western part of Teleorman Plain) and central-eastern (e.g. Bărăgan and Brăila Plains) parts of the Romanian Plain. There, most of the socio-economic indicators with negative impact on the final index had the lowest values (e.g. economically active population, road and railways density, economic dependency rate).

Overall, the analysis of the index values revealed spatial differences which enabled a certain separation between the eastern, central and western parts of the Romanian Plain. Thus, the western part of the study area is characterised by a mosaic-like distribution of the LAU2 falling into all four degrees of socio-economic determinants, with a prevalence of low and medium values. Although known for its predominant rural-agricultural profile, its main socio-economic characteristics (e.g. underperforming subsistence farming, population aging, poor qualification of the labour force) turned this region into a less favourable one for agricultural development as revealed by the generally low values of the final index. This low values point to rather unsustainable farming practices especially in Dolj, Olt and Teleorman counties (Fig. 13).

The central part of the Romanian Plain distinguished itself by a predominance of the high and very high degrees of socio-economic determinants, with a visible concentration in the northern half. This region has the highest socio-economic potential, especially due to the high values of some determinants (e.g. economically active population, young labour and roads and railways density) or the low values of indicators with negative impact on agriculture (e.g. economic dependency rate).

Within the eastern part of the Romanian Plain, some intra-regional spatial differences can be noticed. Here, in the marginal areas, high and very high values of the socio-economic determinants are predominant, while in the central areas, medium and low values prevail. In 
this area, it lays "Insula Mare a Brăilei", the biggest compact agricultural exploitation in Romania, and one of the largest in Europe.

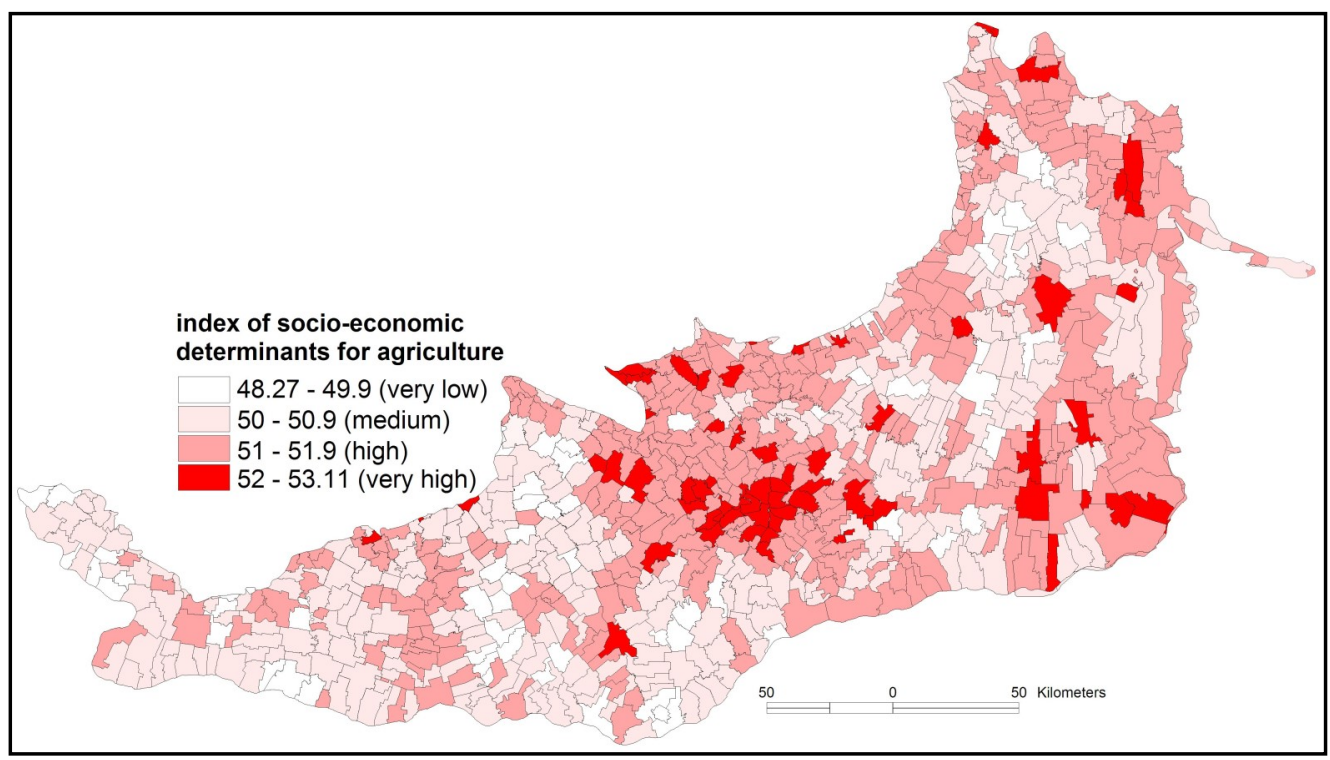

Fig.13 - The index of socio-economic determinants for agriculture in the Romanian Plain

\section{Conclusions}

The Romanian Plain is generally characterised by its high agricultural potential, given the natural environmental conditions and the extended agricultural surface. However, over the last decades, the region has been affected by several demographic processes with impact on the human resources in agriculture (e.g. population aging, out-migration, unemployment) which have been mirrored by some of the indicators selected for the final index: labour renewable index, economically active population, employment in agriculture, vitality index or share of young labour. Moreover, under the structural and functional changes of the post-communist period, the declining industry determined inter-sectoral employment shifts which enabled the absorption of labour by agriculture, especially in rural areas.

The assessment of determinants for agriculture using a complex index based on nine indicators enabled the authors to identify the areas more or less favourable to agriculture based on quantitative and qualitative approaches of human resources and socio-economic development. Thus, depending on the local particularities, the importance and distribution of the nine indicators, as well as the index of socio-economic determinants, significant spatial disparities have been highlighted. Roughly, three major areas have been identified: (1) the western area with a heterogeneous distribution of the index values (low, medium and high), with a predominantly low socio-economic potential for agricultural development; (2) the central area, more compact in terms of the distribution of the index values (mainly high and very high), thus pointing to more favourable conditions for agriculture based on the socio-economic determinants; (3) and the eastern part, which is characterised by two distinctive areas with different development potential for agriculture based on the spatial distribution of the index values: a central area with generally low development potential and a marginal area at the 
contact with the other major relief units (the Subcarpathians to the north-west, the Moldavian Plateau to the north and the Dobrogea Plateau to the east) with a generally high development potential.

Overall, the study revealed that regardless of the regional or local disparities agriculture still provides an important source of minimum income for many households, especially in the rural areas.

The current assessment relies on large datasets used to define the socio-economic determinants of agriculture. However, the selection of data was carried out depending on data availability at smaller spatial scale (LAU2). As a result, the largest share of indicators was population-based referring to age, gender or employment, while the specific social and economic aspects were generally targeted indirectly (e.g. economic dependency rate, economically active population), as they were extracted from the available demographic data.

The lack of statistical data at smaller spatial scales (LAU 2) for large geographical regions (Romanian Plain) on income in agriculture, land fragmentation, productivity, national and foreign investments called for the extraction and compilation of indicators from the available statistics. Moreover, an important step for the improvement of such a study would be to integrate agricultural and environmental policies to support the rural population and the farmers' adaptation to the environmental (e.g. climate change-related issues, land degradation) and socio-economic (e.g. unemployment, population aging) challenges. As a result, the current research might become an important stage in carrying out future complex assessments on the environmental and socio-economic determinants in agriculture, developing strategies and supporting policies in agriculture at different spatial scales.

\section{References}

ANTLE J. M. (1984), Human capital, infrastructure, and the productivity of Indian rice farmers, Journal of Development Economics 14 (1), 163-181.

AUDSLEY E., PEARN K. R., SIMOTA C., COJOCARU G., KOUTSIDOU E., ROUNSEVELL M. D. A., TRNKA M., ALEXANDROV V. (2006), What can scenario modelling tell us about future European scale agricultural land use, and what not?, Environmental Science \& Policy 9 (2), 148-162.

BARNES K. B., MORGAN III J. M., ROBERGE M. C., LOWE S. (2001), Sprawl development: its patterns, consequences, and measurement, Towson University, Retrieved from: www.towson.edu.

BĂLTEANU D. (2016), The Relief. Pericarpathian Regions in Romania, in: Bălteanu D., Dumitraşcu M., Geacu S., Mitrică B., Sima M. (eds.), România. Spaţiu şi Societate, The Publishing House of the Romanian Academy, Bucharest, pp. 82-101.

BĂLTEANU D., DRAGOTĂ C.-S., POPOVICI A., DUMITRAŞCU M., KUCSICSA G., GRIGORESCU I. (2013), Land use and crop dynamics related to climate change signals during the post-communist period in the South Oltenia, Romania, Proceedings of the Romanian Academy B 15 (3), 265-278.

BĂLTEANU D., MITRICĂ B., MOCANU I., SIMA M., POPESCU C. (2016), Caracterizarea geografică a regiunilor de dezvoltare din România, in: Bălteanu D., Dumitraşcu M., Geacu S., Mitrică B., Sima M. (eds.), România. Natură și Societate, The Publishing House of the Romanian Academy, Bucharest, pp. 621-652.

BĂLTEANU D., POPOVICI E.-A. (2010), Land use changes and land degradation in post-socialist Romania, Romanian Journal of Geography 54 (2), 95-105.

BANSE M., VAN MEIJL H., TABEAU A., WOLTJER G., HELLMANN F., VERBURG P. $\mathrm{H}$. (2011), Impact of EU biofuel policies on world agricultural production and land use, Biomass and Bioenergy 35 (6), 2385-2390. 
BAUMANN M., KUEMMERLE T., ELBAKIDZE M., OZDOGAN M., RADELOFF V. C., KEULER N. S., PRISHCHEPOV A. V., KRUHLOV I., HOSTERT P. (2011), Patterns and drivers of post-socialist farmland abandonment in Western Ukraine, Land Use Policy 28 (3), $552-562$.

BENNETZEN E. H., SMITH P., PORTER J. R. (2016), Agricultural production and greenhouse gas emissions from world regions-The major trends over 40 years, Global Environmental Change 37, 43-55.

BINDI M., OLESEN J. E. (2011), The responses of agriculture in Europe to climate change, Regional Environmental Change 11 (1), 151-158.

BINSWANGER H. P., KHANDKER S. R., ROSENZWEIG M. R. (1993), How infrastructure and financial institutions affect agricultural output and investment in India, Journal of Development Economics 41 (2), 337-366.

BOARDMAN J., POESEN J., EVANS R. (2003), Socio-economic factors in soil erosion and conservation, Environmental Science \& Policy 6 (1), 1-6.

BUNEA D. (2011), Cross-County Internal Migration and Convergence in Romania, Annales Universitatis Apulensis Series Oeconomica 13 (2), 508-521.

BUNEA D. (2012), Modern Gravity Models of Internal Migration. The Case of Romania, Theoretical and Applied Economics 19 (4), 127-144.

BUSCH G. (2006), Future European agricultural landscapes-What can we learn from existing quantitative land use scenario studies?, Agriculture, Ecosystems \& Environment 114 (1), 121-140.

CHANT S. (2013), Cities through a "gender lens": a golden "urban age" for women in the global South?, Environment and Urbanization 25 (1), 9-29.

CHIRIȚESCU V., BĂLAN M., BUCUR C. S. (2015), The quality of human resources - a determinant of sustainable rural development in Romania, Romanian Journal of Economics 40 (1), 267-280.

CIUTACU C., CHIVU L. (2007), Calitatea muncii şi a ocupării forţei de muncă în România, European Foundation for the Improvement of Living and Working Conditions, Retrieved from: www.eurofound.europa.eu.

CIUTACU C., CHIVU L., ANDREI J. V. (2015), Similarities and dissimilarities between the EU agricultural and rural development model and Romanian agriculture. Challenges and perspectives, Land Use Policy 44, 169-176.

DUMITRAŞCU M., MOCANU I., MITRICĂ B., DRAGOTĂ C., GRIGORESCU I., DUMITRICĂ C. (2018), The assessment of socio-economic vulnerability to drought in Southern Romania (Oltenia Plain), International Journal of Disaster Risk Reduction 27, 142-154.

EWERT F., ROUNSEVELL M. D. A., REGINSTER I., METZGER M. J., LEEMANS R. (2005), Future scenarios of European agricultural land use: I. Estimating changes in crop productivity, Agriculture, Ecosystems \& Environment 107 (2-3), 101-116.

EUROPEAN COMMISSION (2010), European Employment Observatory Review. Selfemployment in Europe 2010, Publications Office of the European Union, Luxembourg.

FAN S., ZHANG L., ZHANG X. (2002), Growth, inequality, and poverty in rural China: the role of public investments, International Food Policy Research Institute, Washington, DC.

FAN S., ZHANG X. (2008), Public expenditure, growth, and poverty reduction in rural Uganda, African Development Review 20 (3), 466-496.

FRASER E. D. G., STRINGER L. C. (2009), Explaining agricultural collapse: macroforces, micro-crises and the emergence of land use vulnerability in southern Romania, Global Environmental Change 19 (1), 45-53.

GERBENS-LEENES W., NONHEBEL S. (2005), Food and land use. The influence of consumption patterns on the use of agricultural resources, Appetite 45 (1), 24-31.

GRIGORESCU I., KUCSICSA G. (2017), Spatial and temporal dynamics of urban sprawl in the Romanian Plain over the last century, Romanian Journal of Geography 61 (2), 109-123.

GRIGORESCU I., KUCSICSA G., MITRICĂ B. (2015), Assessing spatio-temporal 
dynamics of urban sprawl in the Bucharest metropolitan area over the last century, in: Bicik I., Himiyama Y., Feranec J., Kupkova L. (eds.), Land use/Cover Changes in Selected Regions in the World, vol. X, IGU-LUCC, Prague, pp. 19-27.

IANOŞ I. (1998), Restructurarea economică şi fenomenul de migraţie în România, Revista Geografică 5, 8-13.

IANOŞ I. (2000), Sisteme teritoriale, Technical Press, Bucharest.

LAKO S. P. (1990), The impact of road transport on prices of agricultural produce - a case study of West Gonja District in Ghana, Kwame Nkrumah University of Science and Technology, Kumasi.

LAMBIN E. F., ROUNSEVELL M. D. A., GEIST H. J. (2000), Are agricultural land-use models able to predict changes in land-use intensity?, Agriculture, Ecosystems \& Environment 82 (1-3), 321-331.

MATEOC-SîRB N., MATEOC T., MĂNESCU C., GRAD I. (2014), Research on the labour force from Romanian agriculture, Scientific Papers Series "Management, Economic Engineering in Agriculture and Rural Development" 14 (1), 215-218.

MATTISON E. H. A., NORRIS K. (2005), Bridging the gaps between agricultural policy, land-use and biodiversity, Trends in Ecology \& Evolution 20 (11), 610-616.

MEIYAPPAN P., DALTON M., O'NEILL B. C., JAIN A. K. (2014), Spatial modeling of agricultural land use change at global scale, Ecological Modelling 291, 152-174.

MICHALEK J., ZARNEKOW N. (2012), Application of the rural development index to analysis of rural regions in Poland and Slovakia, Social Indicators Research 105 (1), 1-37.

MIHĂESCU C. (2001), Populaţie şi ocupare: trecut, prezent, viitor, Economic Press, Bucharest.

MOCANU I. (2015), Quality of employment from a geographical perspective. A show case of the Romanian Danube Valley, Romanian Journal of Geography 59 (2), 129-140.

MORTON J. F. (2007), The impact of climate change on smallholder and subsistence agriculture, Proceedings of the National Academy of Sciences of the USA 104 (50), 1968019685.

MOTTET A., LADET S., COQUÉ N., GIBON A. (2006), Agricultural land-use change and its drivers in mountain landscapes: A case study in the Pyrenees, Agriculture, Ecosystems \& Environment 114 (2-4), 296-310.

MUNDLAK Y., LARSON D. F., BUTZER R. (2002), Determinants of agricultural growth in Indonesia, the Philippines, and Thailand, The World Bank, Washington, DC.

NANCU D., MITRICĂ B., PERSU M., MOCANU I. (2015), Population dynamics in the Romanian Danube Valley. Geographical aspects of the young population - labour relations, Agricultural Economics and Rural Development 2, 157-173.

NANCU D., PERSU M. (2004), Studiu de gen asupra spaţiului urban românesc contemporan, Analele Universităţii Spiru Haret. Seria Geografie 7, 129-134.

NILES M. T., BROWN M., DYNES R. (2016), Farmer's intended and actual adoption of climate change mitigation and adaptation strategies, Climatic Change 135 (2), 277-295.

OLESEN J. E., BINDI M. (2002), Consequences of climate change for European agricultural productivity, land use and policy, European Journal of Agronomy 16 (4), 239-262.

OLESEN J. E., TRNKA M., KERSEBAUM K. C., SKJELVÅG A. O., SEGUIN B., PELTONEN-SAINIO P., ROSSI F., KOZYRA J., MICALE F. (2011), Impacts and adaptation of European crop production systems to climate change, European Journal of Agronomy 34 (2), 96-112.

PALOMBA R., KOTOWSKA E. I. (2003), The economically active population in Europe, Council of Europe Publishing, Strasbourg.

PATACCHINI E., ZENOU Y. (2009), Urban sprawl in Europe, Brookings-Wharton Papers on Urban Affairs, 125-149.

PINSTRUP-ANDERSEN P., SHIMOKAWA S. (2007), Rural infrastructure and agricultural development, Revue d'Economie du Développement 15 (4), 55-90.

POPESCU C. (2016), After deindustrialisation: changing urban economy in the Danube valley region, Human Geographies 10 (2), 99-113. 
POPOVICI E.-A., BĂLTEANU D., KUCSICSA G. (2013), Assessment of changes in land-use and land-cover pattern in Romania using Corine Land Cover Database, Carpathian Journal of Earth and Environmental Sciences 8 (4), 195-208.

POPOVICI E.-A., BĂLTEANU D., KUCSICSA G. (2016), Utilizarea terenurilor și dezvoltarea actuală a agriculturii, in: Bălteanu D., Dumitraşcu M., Geacu S., Mitrică B., Sima M. (eds.), România. Natură și Societate, The Publishing House of the Romanian Academy, Bucharest, pp. 329-375.

PREDA M. (ed.) (2003), Issues of the development, population and reproduction health at national level and study-cases. Romania, UNEPA, Bucharest.

RENWICK A., JANSSON T., VERBURG P. H., REVOREDO-GIHA C., BRITZ W., GOCHT A., MCCRACKEN D. (2013), Policy reform and agricultural land abandonment in the EU, Land Use Policy 30 (1), 446-457.

REY BENAYAS J. M., MARTINS A., NICOLAU J. M., SCHULZ J. J. (2007), Abandonment of agricultural land: an overview of drivers and consequences, CAB Reviews: Perspectives in Agriculture, Veterinary Science, Nutrition and Natural Resources 2 (57), 1-14.

ROUNSEVELL M. D. A., ANNETTS J. E., AUDSLEY E., MAYR T., REGINSTER I. (2003), Modelling the spatial distribution of agricultural land use at the regional scale, Agriculture, Ecosystems \& Environment 95 (2-3), 465-479.

ROUNSEVELL M. D. A., EWERT F., REGINSTER I., LEEMANS R., CARTER T. R. (2005), Future scenarios of European agricultural land use: II. Projecting changes in cropland and grassland, Agriculture, Ecosystems \& Environment 107 (2-3), 117-135.

SERBAN A. C. (2012), Aging population and effects on labour market, Procedia Economics and Finance 1, 356-364.

SHIMOKAWA S. (2007), Rural Road Investments, Agricultural Development, and Poverty Alleviation in China, in: Pinstrup-Andersen P., Cheng F. (eds.), Food Policy for Developing countries: Case Studies, Cornell University, New York, pp. 1-10.

SIMA M., POPOVICI E.-A., BĂLTEANU D., MICU D. M., KUCSICSA G., DRAGOTĂ C., GRIGORESCU I. (2015), A farmer-based analysis of climate change adaptation options of agriculture in the Bărăgan Plain, Romania, Earth Perspectives 2 (5), 1-21.

SMIT B., SKINNER M. W. (2002), Adaptation options in agriculture to climate change: a typology, Mitigation and Adaptation Strategies for Global Change 7 (1), 85-114.

SMITH P., BUSTAMANTE M. (eds.) (2014), Agriculture, forestry and other land use (AFOLU), in: Edenhofer O., Pichs-Madruga R., Sokona Y., Farahani E., Kadner S., Seyboth K., Adler A., Baum I., Brunner S., Eickemeier P., Kriemann B., Savolainen J., Schlömer S., Von Stechow C., Zwickel T., Minx J. C. (eds.), Climate Change 2014: Mitigation of Climate Change. Contribution of Working Group III to the Fifth Assessment Report of the Intergovernmental Panel on Climate Change, Cambridge University Press, Cambridge, pp. 811-922.

SZOCS B. M. A., RODRIGUEZ BEPERET M., SROVNALOVA A. (2015), Land grabbing in Romania, Eco Ruralis, Retrieved from: www.ecoruralis.ro.

TACOLI C. (2012), Urbanization, gender and urban poverty: paid work and unpaid carework in the city, IIED \& UNFPA, London.

TACOLI C., MABALA R. (2010), Exploring mobility and migration in the context of ruralurban linkages: why gender and generation matters, Environment and Urbanization 22 (2), 389 $-395$.

TEMME A. J. A. M., VERBURG P. H. (2011), Mapping and modelling of changes in agricultural intensity in Europe, Agriculture, Ecosystems \& Environment 140 (1-2), 46-56.

TOCCO B., DAVIDOVA S., BAILEY A. (2014), Labour adjustments in agriculture: evidence from Romania, Studies in Agricultural Economics 116 (2), 67-73.

URUCU V., NANCU D. (1992), Feminizarea oraşelor României, Sociologie Românească 3 (4), 443-445.

VAN ITTERSUM M. K., EWERT F., HECKELEI T., WERY J., ALKAN OLSSON J., ANDERSEN E., BEZLEPKINA I., BROUWER F., DONATELLI M., FLICHMAN G., OLSSON L., RIZZOLI A. E., VAN DER WAL T., WIEN J. E., WOLF J. (2008), Integrated assessment of agricultural systems - A component-based framework for the European Union (SEAMLESS), 
Agricultural Systems 96 (1-3), 150-165.

VAN MEIJL H., VAN RHEENEN T., TABEAU A., EICKHOUT B. (2006), The impact of different policy environments on agricultural land use in Europe, Agriculture, Ecosystems \& Environment 114 (1), 21-38.

VAN VLIET J., DE GROOT H. L. F., RIETVELD P., VERBURG P. H. (2015), Manifestations and underlying drivers of agricultural land use change in Europe, Landscape and Urban Planning 133, 24-36.

VERBURG P. H., SCHOT P. P., DIJST M. J., VELDKAMP A. (2004), Land use change modelling: current practice and research priorities, GeoJournal 61 (4), 309-324.

VERT C. (1995), Analiză geodemografică. Manual practic, Mirton Press, Timişoara.

Initial submission: 15.01 .2018

Revised submission: 29.03.2018

Final acceptance: 14.05.2018

Correspondence: Institute of Geography, Romanian Academy, 12 Dimitrie Racovita Street, 023994, Sector 2, Bucharest, Romania.

Email: mocanitai@yahoo.com 
